\title{
SOCIAL FUNCTIONS OF BODILY MODIFICATIONS IN ANCIENT TIMES AND NOW
}

\author{
Viktoriia Harbuzoval, Uliana Yatsyshyn ${ }^{2}$ \\ Lviv Polytechnic National University, Lviv, Ukraine \\ ${ }^{1}$ Student of bachelor's program "Sociology", Department of Sociology and Social Work \\ ${ }^{2}$ Ph.D., Associate Professor, Department of Sociology and Social Work
}

Background: At all periods of human development, bodily modifications have played an important role in the processes of communication and interpersonal interaction. We are interested in the dynamics of changes of social functions in society. We will turn to these aspects in a historical retrospective to determine their differences and characteristics.

Purpose: to establish changes in the social functions of bodily modifications of ancient and modern times.

Methods: We used theoretical research methods to analyze and compare the social functions of bodily modifications in ancient times and now. The empirical method of secondary data analysis was used to analyze the relevance of social functions of bodily modifications that have survived from ancient times to the present.

Results: theoretical and empirical analysis shows that the social functions of bodily modifications have existed since ancient times. Most of the functions remain relevant, but the protective function has been transformed into aesthetic.

Conclusion: Comparing the social functions of bodily modifications in traditional societies and in modern times, it can be noted that most of them have preserved.

Keywords: bodily modifications, social functions, ancient times, nowadays.

Термін «тілесні модифікації» розглядається багатьма науками і має різне трактування. В загальному понятті, «тілесні модифікації» - це навмисна зміна частин людського тіла. В соціології модифікації тіла розглядаються, в першу чергу, як спосіб самопрезентації в процесі соціальної взаємодії.

Вивченню аспектів тілесних модифікацій приділяли увагу багато дослідників, наприклад, С. Ворошилін, Ю. Ричакова, М, Меднікова. У своїх дослідженнях вони відзначили факт широкого поширення феномену тілесних модифікацій серед більшості етносів.

На всіх етапах розвитку культури тілесні модифікації відігравали важливу роль у процесах комунікації та міжособистісної взаємодії. Звідси постає питання про соціальні функції тілесних модифікацій. Ми розглядатимемо ці аспекти в історичній ретроспективі з метою встановлення їх відмінностей та особливостей.

Історія практики тілесних модифікацій налічує більше шістдесяти тисяч років. Їх виникнення, найвірогідніше відноситься до епохи палеоліту. Доказом того, що даний феномен існував в первісному суспільстві, $є$ зміни частин муміфікованих тіл, які збереглися протягом шести тисяч років. Можна припустити, що внутрішні посили до ототожнення себе 3 кимось або чимось з'явились в той час, коли людина виділилась з світу тварин. В таких умовах тілесні модифікації виконували функцію соціалізації. Багато явищ, фактів та ситуацій, які виникали протягом життєдіяльності індивіда, спонукало його зафіксувати найважливіше у вигляді різноманітних модифікацій тіла. Так, етнограф Н. Міклухо-Маклай зазначав, що татуювання для первісних людей сприяло відокремленню людей від тваринного світу та становленню в якості соціального суб'єкта. На думку М. Меднікової, виникнення та поширення тілесних модифікацій було обумовлене трансформацією іiі захисної функції. На відміну від функції соціалізації, індивід змінював своє тіло для захисту, намагаючись таким чином «злитись» 3 навколишнім світом.

Виникнення тілесних модифікацій є випадковим, природнім явищем. Наприклад, шрами, які залишались на тілі людини після полювання або битви створювали малюнок або символ. Розмір, кількість шрамів, їх розташування дозволяло впізнавати серед представників того чи іншого племені досвідчених бійців, воїнів, мисливців. Ставалось, що чоловіки 3 певних 
причин не отримували серйозних ушкоджень, що спонукало їх створювати сліди на тілі навмисно. Існував обряд ініціації юнаків: коли вони досягали певного віку, на їх тіло наносили «священний текст», який дозволяв їм стати повноцінними мисливцями або воїнами. Часто саме під час цих подій різноманітні види тілесних модифікацій підкреслювали стать, вік, приналежність індивіда до певного суспільства та його статус. В таких випадках тілесні модифікації виконували статусну функцію (Ворошилин, С., 2012).

У X столітті в Китаї виникла традиція бинтування ніг. 3 раннього дитинства матері бинтували своїм донькам ноги та одягали на них затісні туфлі, які не знімалися місяцями. Це робилося для того, аби дівчина могла вдало вийти заміж. Ще одна традиція існує в племені падаунг. Жінки цього племені носять мідні кільця - спіралі на шиї, візуально ії подовжуючи. На сьогоднішній день в деяких племенах збереглися традиційні, примусові види тілесних модифікацій. В Африканських племенах дівчатка віком 12-15 років проходять традицію підготовки до шлюбу, яка полягає в обрізанні жіночих статевих органів. Цей спосіб плем’я використовує для того, щоб вказати жінкам, що вони не мають право на отримання задоволення від статевого акту, а їхня роль полягає у наданні його чоловікам. Ще однією традицією є «розкатування грудей». Найбільше вона розповсюджена в Нігерії. Коли дівчина досягає періоду статевого дозрівання, їі матір починає розгладжувати груди донці, ця процедура робиться за допомогою розпеченого каміння, яким «розтирають» груди, тугих пов'язок, дерев'яних качалок та лопаток. Це робиться матерями, які хочуть вберегти своїх дітей від раннього залицяння хлопців, одруження та згвалтувань. Перелічені модифікації виконують функцію контролю над тілом жінок.

Для давніх людей була характерна міфологізація всіх сфер життєдіяльності. На думку Ю. Ричакової, татуювання та шрамування використовувались не тільки для інформування про соціальний статус та приналежність до племені, а й в якості оберегів. Людство вірило, що ці «обереги» дарували здібності та захищали від злих духів. Таким чином, можемо виділити захисну функцію. Саме ця функція, на думку Ю. Ричакової, втратила свій влив та перетворилася на естетичну. Зараз тілесні модифікації відображають не традиції, вірування групи, до якої належить індивід, а світогляд та цінності його самого (Рычкова, Ю., 2005).

Зараз в більшості випадків процес тілесних модифікацій визначає новий статус індивіда, виводить його на якісно новий рівень. Модифікація тіла шляхом хірургічного втручання на даний момент $є$ дорогою процедурою, що також говорить про соціальний статус та матеріальний стан людини. Якщо жінка здійснює модифікації грудей, губ, сідниць, - це говорить про високий матеріальний стан її самої або iї чоловіка, професійну необхідність, бажання подобатись протилежній статі або слідування моді. В такому випадку проявляються і естетична функція, і статусна.

Якщо розглядати татуювання, можна сказати, що ця модифікація в наш час $є$ дуже поширеною і виконує лише естетичну функцію. Цей вид тілесної модифікації здійснюють люди будь-якого віку (офіційно - починаючи з повноліття), будь якого соціального статусу, статі. Особистість сама обирає який візерунок та на яку частину тіла вона хоче нанести, який сенс хоче вкласти в це. Проте, збереглись деякі стереотипи щодо цього феномену. Ще 20-30 років тому зберігалась думка, що татуювання на тілі людини - ознака того, що вона була ув'язненою, а візерунок показував причину ув'язнення та статус людини серед інших ув'язнених. I до сьогодні прийнято вважати, що людині з татуюванням буде важко знайти роботу, оскільки татуювання - ознака кримінального минулого.

Пірсинг, яскраве волосся, нестандартний образ сприймаються суспільством як ознаки приналежності до певної субкультури, переважно молодіжної. Це прояв функції соціалізації: молодь хоче показати завдяки тілесним модифікаціям світогляд, інтереси, переваги у виборі оточення. Все це свідчить про те, що в сучасному світі в дійсності збереглись основні функції модифікації тіла.

Аналіз результатів соціологічних досліджень на тему «Соціальні модифікації» свідчить про наявність описаних нами соціальних функцій тілесних модифікацій в сучасному суспільстві. У 2014 р. корейське агентство з вивчення споживчого попиту (КСА) провело опитування 1000 пацієнтів пластичних хірургів. 3 них: 70\% відповіли, що здійснили пластичну операцію для 
поліпшення своєї зовнішності. 14.5\% вважають, що результат покращив їх перспективи на отримання підвищення по службі або перехід на більш престижну роботу (Evans, S., 2014). 3 7 по 16 вересня 2019 року в Україні було проведено дослідження 3 питання бажання здійснювати татуювання соціологічною групою Research \& Branding Group, в ході якого було опитано 2001 респондент віком від 18 років. Майже 70 відсотків опитаних причиною свого рішення зробити татуювання назвали бажання стати більш привабливими, поліпшити свою зовнішність. Також відсотків 60 стверджували, що розраховували за допомогою натільного малюнка підвищити своє соціальне становище. Також 30 відсотків респондентів підтвердили, що тату для них стало знаком початку нового життя і змін у житті. Як в першому, так і другому дослідженні результати показують актуальність статусної, естетичної та функції соціалізації.

Якщо зіставити соціальні функції тілесних модифікацій в традиційних суспільствах та в сучасному, то можна зазначити, що більшість з них збереглися до сьогоднішнього дня. Розглянемо найбільш важливі функції тілесних модифікацій, властиві народам, які жили в умовах первісно - общинного устрою або первинного класового суспільства, які не втратили актуальності і в наш час. Перш за все, необхідно сказати про функцію соціалізації. Тілесні модифікації протягом всієї історії людства були розпізнавальним знаком етносу, вказівником приналежності до певного суспільства, визначали соціальну приналежність їх носія. I в наш час люди використовують татуювання, пірсинг, шрамування як символи приналежності до певної субкультури, світогляду, культури тощо. Продовженням функції соціалізації $\epsilon$ cmamycна. Модифікації тіла відображають не лише життєвий шлях людини, але й становище на в ієрархічній структурі його соціальної групи, його статус та ролі. Для кожного окремого індивіда тілесні модифікації виконують естетичну функцію для вираження своїх поглядів, особистого досвіду, цінностей.

Отже, ми розглянули соціальні функції тілесних модифікацій первісного суспільства та сучасного. Більшість функцій давніх часів не втратили актуальності і в наш час, проте одна функція - захисна - трансформувалась у естетичну.

\section{References}

Evans, S. (2014). Victims of a Craze for Cosmetic Surgery. BBC News Online, 15. Retrieved from: https://www.bbc.com/news/magazine-30295758

Rychkova, U.(2005). Stylish tattoos from A to Z: The art of surprise, seduce, shock. M .: Ripol Klassik.

Voroshilin, S. (2012). Self-harm and attraction to bodily modifications as partial violations of the instinct of self-preservation. Suicidology, 3 (4 (9)), 40-52.

\section{Список використаних джерел}

Evans, S. (2014). Victims of a Craze for Cosmetic Surgery. BBC News Online, 15. Отримано 3: https://www.bbc.com/news/magazine-30295758

Ворошилин, С. (2012). Самоповреждения и влечения к модификации тела как парциальные нарушения инстинкта самосохранения. Суицидология, $3(4$ (9)), 40-52.

Рычкова, Ю. (2005). Стильные тату от А до Я: Искусство удивлять, соблазнять, шокировать. М.: Рипол-классик.

\section{Contact information:}

Harbuzova Viktoriia viktoriia.harbuzova.so.2016@1pnu.ua

Yatsyshyn Uliana

Uliana.V.Yatsyshyn@1pnu.ua 